\title{
OVIPOSITION OF THE GALL WASP LEPTOCYBE INVASA (HYMENOPTERA: EULOPHIDAE) AND MORPHOLOGICAL CHANGES IN EUCALYPTUS SPP. GENOTYPES SUSCEPTIBLE
}

\author{
José Oliveira Dantas ${ }^{1 *}$, José Roberto Vieira Aragão ${ }^{2}$, Claudio Sergio Lisi ${ }^{3}$, Elizamar Ciríaco da Silva ${ }^{4}$, Renata \\ Lima de Anchieta $^{5}$, Genésio Tâmara Ribeiro ${ }^{6}$ \\ ${ }^{1}$ Instituto Federal de Sergipe, Departamento de Agroecologia, São Cristóvão, Sergipe, Brasil. E-mail: josedantas336@gmail.com \\ ${ }^{2}$ Universidade Federal de Sergipe, Departamento de Biologia, São Cristóvão, Sergipe, Brasil. E-mail: craniusru@ @amil.com \\ ${ }^{3}$ Universidade Federal de Sergipe, Departamento de Biologia, São Cristóvão, Sergipe, Brasil. E-mail: clcslisi@ gmail.com \\ ${ }^{4}$ Universidade Federal de Sergipe, Departamento de Biologia, São Cristóvão, Sergipe, Brasil. E-mail: elizaciriaco@ gmail.com \\ ${ }^{5}$ Universidade Federal de Sergipe, Departamento de Biologia, São Cristóvão, Sergipe, Brasil. E-mail: renata_anchieta@ hotmail.com \\ ${ }^{6}$ Universidade Federal de Sergipe, Departamento de Ciências Florestais, São Cristóvão, Sergipe, Brasil. E-mail: genesiotr@ hotmail.com
}

Received for publication: 02/03/2020 - Accepted for publication: 07/05/2020

\begin{abstract}
Resumo
Oviposição de Leptocybe invasa (hymenoptera: eulophidae) e alterações morfológicas em eucalyptus spp. genótipos sensíveis. O eucalipto é cultivado em todo o mundo para diversos fins, como para a produção de madeira, lenha, celulose e óleos essenciais. O eucalipto foi introduzido no Brasil em 1904, e seu cultivo vem crescendo desde então, com cerca de 5,57 milhões de hectares de plantações em 2014. Esse aumento nas plantações favoreceu as populações de insetos nativos, alguns insetos se tornaram pragas, enquanto outras pragas de insetos exóticos foram introduzidos, como a vespa (Leptocybe invasa), que se deposita na nervura central das folhas, pecíolos e brotações jovens, causando a formação de galhas que comprometem o crescimento normal das plantas. Com o objetivo de avaliar as alterações morfológicas nos genótipos de Eucalyptus spp., causados pela formação de galhas, foi estudada a anatomia, qualitativa e quantitativamente dos feixes vasculares. Os resultados mostraram que a oviposição ocorreu nos 4 genótipos estudados, porém a formação de galhas não ocorreu no genótipo 1404, classificado como resistente, enquanto a suscetibilidade foi baixa no genótipo 1277, media no genótipo 1724 e muito alta no genótipo 1262. Os feixes vasculares e as células do parênquima nas folhas e pecíolos foram desorganizados. O surgimento de insetos adultos causou rupturas nas células vasculares, parênquima e epiderme, resultando em necrose e seca foliar.

Palavras-chave: Pragas florestais; Vespa da galha; Silvicultura.
\end{abstract}

\section{Abstract}

Eucalyptus is grown worldwide for many purposes, as for production of wood, firewood, cellulose and essential oils. Eucalyptus was introduced into Brazil in 1904, and its cultivation has been growing since that time, with about 5.57 million hectares of plantations in 2014. This increase in plantations has favored the native insect populations, some insects have become pests, while other exotic insect pests were introduced such as the gall wasp (Leptocybe invasa), which oviposits in the midrib of leaves, petiole, and in young shoots, causing the formation of galls which compromise the normal growth of plants. In order to evaluate the morphological changes in genotypes of Eucalyptus spp., caused by the galls formation, the anatomical alterations qualitative and quantitatively of the vascular bundles were studied. The results showed that oviposition occurs in the four genotypes studied, but the genotype 1404 is resistant to gall formation, while the susceptibility is low in genotype 1277, medium in genotype 1724 and very high in genotype 1262. The vascular bundles and parenchyma cells in the leaves and petioles were disorganized. The emergence of adult insects caused ruptures in vascular, parenchyma and epidermal cells, resulting in necrosis and foliar droughtness.

Keywords: Forest pests; Gall wasp; Silviculture.

\section{INTRODUCTION}

The Eucalyptus tree is native to Australia, Tasmania and other islands of Oceania with about 700 recognized species, and about 20 of them are commercially grown worldwide (BRISOAL; DEMARCO 2011). Eucalyptus plantations are economically important in several countries (DITTRICH-SCHRODER et al. 2012) with approximately 20 million hectares of planted area in more than 100 countries (MYBURG et al. 2014). In Brazil, Eucalyptus plantation reached 5.57 million hectares in 2014, destined to the wood production, pulp and paper, as fuel and coal in the steel industry and other uses (IBA 2015).

Eucalyptus was introduced into Brazil in 1904 and due to extremely favorable conditions of climate and soil it achieves rapid growth, reaching the highest productivity indexes in the world. The silviculture with Eucalyptus in Brazil was favored by genetic improvement through genetic selection criteria, where maximization of desirable traits is sought (TUNG et al. 2010), mainly being high quality cellulose. On the other hand, the expansion of Eucalyptus plantations in Brazil favored the increase of the populations of several native insects and exotic pest insects were introduced, including the Eucalyptus gall wasp Leptocybe invasa Fisher \& La Salle, 2004 (Hymenoptera: Eulophidae). Originated in Australian, L. invasa was reported for the first time in 2000 in the Middle East, and at present the pest has been registered in Europe, Asia, Africa, Oceania and America 
(MENDEL et al. 2004; TONG et al. 2016). It was recorded for the first time in Brazil in 2008, in the northeast of Bahia State. The wasp oviposition in leaves, young branches and petioles causing the formation of gall of several Eucalyptus species (MENDEL et al. 2004; THU et al. 2009; PETRO et al. 2015).

Galls are alterations of plant tissues caused by gall-inducing stimuli contained in saliva injected during feeding by aphids, in maternal secretions injected during oviposition of sawflies, in larval secretions of unknown origin from cynipid galls wasps (ALMADA; FERNANDES 2011; RICHARDSON et al. 2017). It causes cell hypertrophy and tissue hyperplasia (FERREIRA; ISAIAS 2013; MAGALHÃES et al. 2014), responsible for the various structural gall shapes (ISAIAS et al. 2013, 2015). The study of galls is important in silviculture and agriculture because of the damage they cause to cultivated plants.

Several crosses between Eucalyptus species were performed in the search for plants showing commercial interesting traits, such as cellulose of good quality and easy bleaching, these crosses produced a large number of hybrids with peculiar characteristics including different resistance and susceptibility to wasp attacks (THU et al. 2009; NYEKO et al. 2010).

This susceptibility can be promoted by physical and/or chemical factors, since physical factors can prevent the entry of pathogens or arthropods in the tissues, or the insect from causing more damage (AOYAMA; LABINAS, 2012).

Eucalyptus and hybrid species present different levels of susceptibility to the attack of L. invasa (MENDEL et al. 2004; THU et al. 2009), which depends on environmental and genetic factors (WILCKEN et al. 2015). Eucalyptus grandis Hill ex. Maiden, Eucalyptus camaldulensis Dehn and Eucalyptus tereticornis Sm are considered more susceptible to the development of $L$. invasa-induced galls (THU et al. 2009; NUGNES et al. 2015), and this susceptibility is transmitted to offspring as observed in the evaluated 1277 and 1262 hybrids. The susceptibility level of the eucalyptus genotypes is related to the number of galls and consequently to the structural alterations of the plants. Some anatomical characteristics can be modified by the galls, as they depresses hydraulic conductance of stem and leaf (TONG et al. 2016), disrupts and affects the transport of substances by xylem and phloem (GONZALEZ; SOLIS, 2015) and deforms and reduces leaf area.

Since the work related to the morphophysiological changes of the eucalyptus is still scarce, we asked if the gall wasp oviposites in resistant genotypes of Eucalyptus and if the formation of galls can disorganize the conductive tissues. Thus, the objective of this work was to evaluate in vascular bundles of leaves, petiole and young branches the anatomical changes caused by the oviposition of the wasp in Eucalyptus genotypes.

\section{MATERIAL AND METHODS}

\section{Place of study and plant material}

Four genotypes of hybrids Eucalyptus (coded as 1404, 1724, 1277 and 1262) (Table 1) were supplied by Bahia Specialty Cellulose (Copener Florestal) and were grown in five liter plastic buckets with substrate composed of chermozen, sand and bovine manure (3:1:1) in the nursery of the Federal University of Sergipe (UFS), São Cristóvão Campus. Genotype 1404 is resistant to gall formation being as standard plant, whereas genotypes 1724, 1277 and 1262 show different degrees of susceptibility to gall development due to the oviposition of L. invasa. The susceptible genotypes used in this experiment were infested with the gall wasp.

Table 1: Parental and susceptibility of Eucalyptus genotypes provided by BSC/Copener Florestal.

Tabela 1: Parentais e susceptibilidade de genótipos de Eucalyptus fornecidos por BSC/Copener Florestal.

\begin{tabular}{llccc}
\hline \multirow{2}{*}{$\begin{array}{c}\text { Eucalyptus } \\
\text { Genotype }\end{array}$} & Susceptibility & \multicolumn{2}{c}{ Affiliation } & Origin \\
\cline { 3 - 4 } 1404 & Resistant & E. urophylla & E. spp. & Inhambupe / Copener \\
1277 & Low susceptible & E. spp & E. spp & - \\
1224 & $\begin{array}{l}\text { Medium } \\
\text { susceptible }\end{array}$ & E. grandis & E. camaldulensis & Sátiro Dias/Copener \\
1262 & Very high & E. grandis & E. urophylla & Inhambupe / Copener \\
\hline
\end{tabular}

\section{Determination of susceptibility genotypes Eucalyptus}

The level of susceptibility of Eucalyptus genotypes was obtained by adapting the Fournier Index adapted (1975) used in the phenology study, which allows estimating the percentage of intensity of a given event in the plants. Using a semi-quantitative scale with intervals of $25 \%$, it allows to group the genotypes into five categories ( 0 to 4 ), where 0 is the absence of the event; 1 the magnitude of the event between $1 \%$ and $25 \% ; 2$ the 
magnitude of the event between $26 \%$ and 50\%; 3 the magnitude of the event between $51 \%$ and $75 \%$ and 4 the magnitude of the event between $76 \%$ and $100 \%$. In this work we evaluated the incidence of gall in the plants, considered 0 for resistant genotypes, 1 low susceptibility, 2 medium susceptibility, 3 high susceptibility and 4 very high.

\section{Anatomical analyses}

In order to characterize the morphological changes, the plants were photographed with an OLYMPUS ${ }^{\circledR}$ digital camera and ZEISS ${ }^{\circledR}$ stereoscopic microscope at the Forest Entomology Laboratory of UFS (LEFLO).

In order to characterize the anatomical alterations of the vascular bundles of the Eucalyptus genotypes caused by the galls, branches of the plants was studied on Plant Anatomy and Dendroecology Botanical Laboratory. From 3 plants of each Eucaliptus genotypes, 3 leaves of each plant (9 leaves of each genotype, 36 leaves in total) with petioles and proximal young shoots were separated to make cuts of transversal sections by free-hand and in a HYRAX S $50^{\circledR}$ microtome $(20 \mu \mathrm{m}$ thick) by semi-permanent mounts were prepared.

Ten histological sections of each plant structures (in vivo) were assembled on slides to be observe under a BIOVAL ${ }^{\circledR}$ microscope and photographed with a SAMSUNG ${ }^{\circledR}$ digital camera (magnification by $100-400 \mathrm{x}$ ). After, these histological sections were dehydrated in alcoholic series (50\%, 70\% and 90\%), and colored with alcoholic Safranin solution (1\%) and placed in permanent slides for new section observation end photos. This histological procedure was read. All histological sections from 4 Eucalyptus genotypes was in collection ASEw. Anatomical alterations of the vascular bundles were characterized by morphometry, where the areas of the vascular bundles were measured using the IMAGE-PRO PLUS ${ }^{\circledR}$ program.

\section{Experimental design and statistical analysis}

A completely randomized design was used with four Eucalyptus genotypes with different levels of wasp attack. Anatomical analysis was performed using 10 replications per genotype. For anatomical traits, the four genotypes were statistically compared using analysis of variance (ANOVA) followed by the Dunnet test $(\mathrm{P}<0.05)$ in order to evaluate the differences between the resistant and susceptible genotypes.

The bundle areas of the four genotypes were statistically compared using analysis of variance (ANOVA) followed by the Dunnet test in order to evaluate the differences between the resistant and susceptible genotypes.

\section{RESULTS}

Ovipositions of gall wasp were observed in resistant genotypes of Eucalyptus (Figure 1), however there is no formation of the gall, such as the genotype 1404. Genotype 1404 has lanceolate leaves with a conspicuous midrib, secondary veins disposed in peninervea, and petioles without morphological alterations resistant to gall formation (Figure 2A). Genotype 1277 presents a degree of low susceptibility with the presence of gall in the rib leaves and petioles, but in small numbers (Figure 2D, E, F).
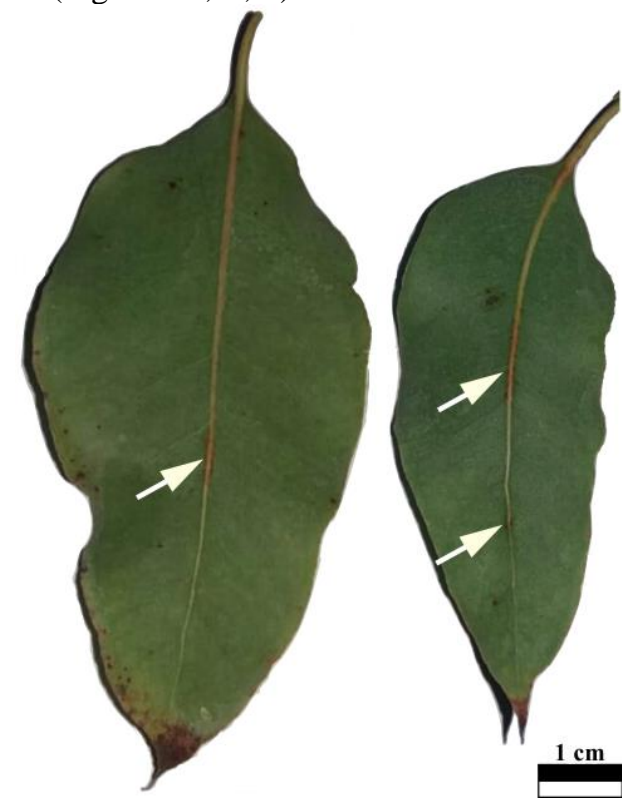

Figure 1. Oviposition of L. invasa (arrow) on leaves of resistant genotypes of the Eucalyptus.

Figura 1. Oviposição de L. invasa (seta) em folhas de genótipos resistentes de Eucalyptus.

FLORESTA, Curitiba, PR, v. 51, n. 3, p. 668-676, jul/set 2021. 
Genotype 1724 showed a higher amount of gall in the midrib, petioles and young branches (Figure 2G, $\mathrm{H}, \mathrm{I})$, the number of galls is even higher in the 1262, which was considered as very high susceptibile. In the genotype 1262, a fairly high infestation of the L. invasa wasp was observed in the petiolate midrib of leaves, petioles and young branches, causing loss of the apical dominance of its branches, and developing a process of ramification or hight sprouting (Figure 2J, K, L). According to Fournier index adapted (1975), Eucalyptus genotypes were classified as resistant to gall formation (1404), low susceptibile (1277), medium susceptibile (1724) and very high susceptibile (1262).
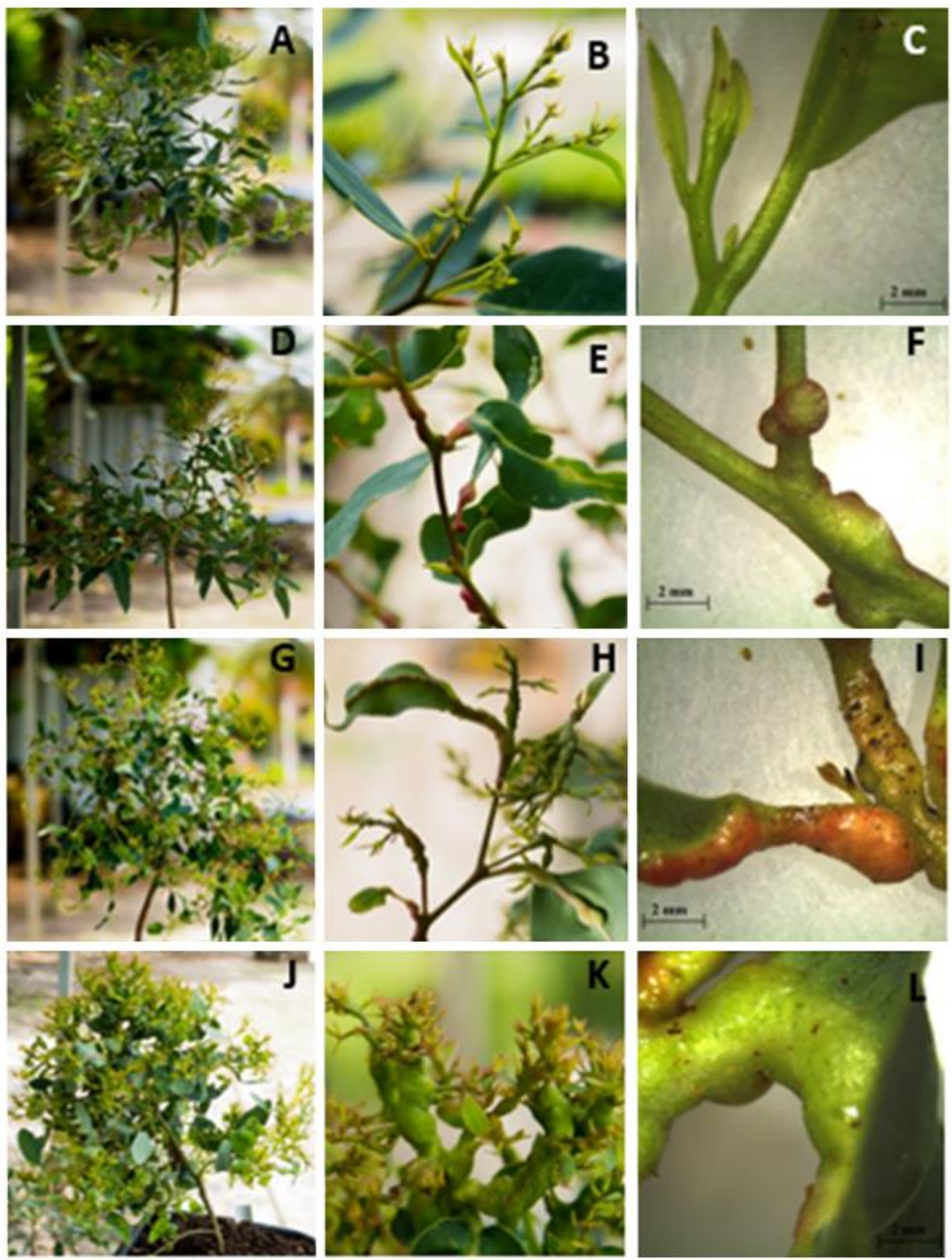

Figure 2: Eucalyptus genotypes (A, B, C= 1404, D, E, F= 1724, G, H, I= 1277, J, K, L= 1262) in macroscopic photography (A, B, D, E, G, H, J, K) and using stereomicroscopy (C, F, I, L, bar 2mm) attacked by Leptocybe invasa $(\mathrm{a}=1404, \mathrm{~b}=1724, \mathrm{c}=1277, \mathrm{~d}=1262)$. ( $\mathrm{A}, \mathrm{B}, \mathrm{C})$ : resistant genotype; $(\mathrm{D}, \mathrm{E}, \mathrm{F})$ : susceptible genotype (low); (G, H, I): susceptible genotype (medium); (J, K, L): susceptible (very high) genotype. 
Figura 2: Genótipos de Eucalyptus (A, B, C = 1404, D, E, F = 1724, G, H, I = 1277, J, K, L = 1262) na fotografia macroscópica (A, B, D, E, G, H, J, K) e usando estereomicroscopia (C, F, I, L, bar 2mm) atacada por Leptocybe invasa $(a=1404, b=1724, c=1277, d=1262)$. $(A, B, C)$ : genótipo resistente; (D, E, F): genótipo suscetível (baixo); $(\mathrm{G}, \mathrm{H}, \mathrm{I})$ : genótipo suscetível (médio); (J, K, L): genótipo suscetível (muito alto).

The Eucalyptus genotypes without attack presented in the leaves vascular bundles in open arc delimited by parenchyma and scattered fibers (Figure 3 A, B, C, D), a subepidermal collenchyma was also observed. This presented subepidermal collenchyma surrounding the cortical parenchyma, and this surrounds the vascular bundles of phloem and xylem.
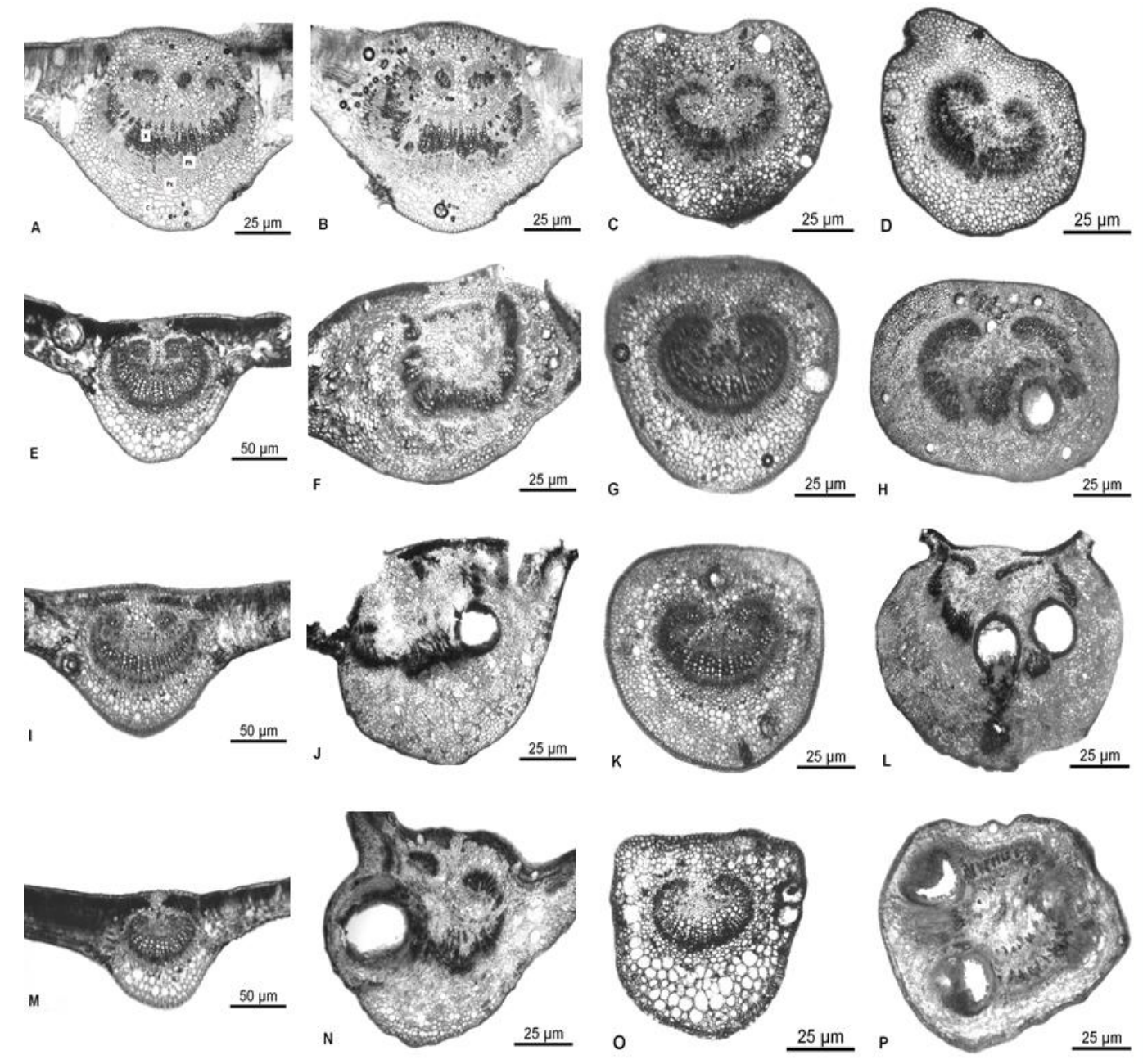

Figure 3: Transverse sections of the leaves (1 and 2) and petiole (3 and 4) of four Eucalyptus genotypes (A, B, C, $\mathrm{D}=1404, \mathrm{E}, \mathrm{F}, \mathrm{G}, \mathrm{H}=1724, \mathrm{I}, \mathrm{J}, \mathrm{K}, \mathrm{L}=1277, \mathrm{M}, \mathrm{N}, \mathrm{O}, \mathrm{P}=1262$ ) attacked by Leptocybe invasa. Resistant genotype: (A, B, C, D); susceptible genotype (low): (E, F, G, H); susceptible genotype (medium): (I, J, K, L); susceptible genotype (very high): (M, N, O, P); leaves without attack (A, E, I, $\mathrm{M})$; leaves with attack $(\mathrm{F}, \mathrm{J}, \mathrm{N})$; petiole without attack $(\mathrm{C}, \mathrm{G}, \mathrm{K}, \mathrm{O})$; petiole with attack $(\mathrm{H}, \mathrm{L}, \mathrm{P})$; bars 1 and 2: $25 \mu \mathrm{m}$; bar 3: $50 \mu \mathrm{m}$.

Figura 3: Secções transversais das folhas (1 e 2) e pecíolos (3 e 4) de quatro genótipos de Eucalyptus (A, B, C, D $=1404, \mathrm{E}, \mathrm{F}, \mathrm{G}, \mathrm{H}=1724, \mathrm{I}, \mathrm{J}, \mathrm{K}, \mathrm{L}=1277, \mathrm{M}, \mathrm{N}, \mathrm{O}, \mathrm{P}=1262$ ) atacado por Leptocybe invasa. Genótipo resistente: (A, B, C, D); genótipo suscetível (baixo): (E, F, G, H); genótipo suscetível (médio): (I, J, K, L); genótipo suscetível (muito alto): (M, N, O, P); folhas sem ataque (A, E, I, M); folhas com ataque $(\mathrm{F}, \mathrm{J}, \mathrm{N})$; pecíolo sem ataque $(\mathrm{C}, \mathrm{G}, \mathrm{K}, \mathrm{O})$; pecíolo com ataque $(\mathrm{H}, \mathrm{L}, \mathrm{P})$; barras $1 \mathrm{e}$ 2: $25 \mu \mathrm{m}$; barra 3: $50 \mu \mathrm{m}$. 
The structures of the central vein from the leaves with first attack level (Figure 3F) presented disarrangement of the vascular bundles and parenchyma to. The vascular bundles begin to lose their structure in open arc, while the cortical parenchyma increases its area of comprehensiveness and the collenchyma cells are diffuse in the sub epidermis. Under this same level of attack, this tissues in petioles also showed changes (Figure $3 \mathrm{~F})$, with the formation of a flat arch and disorganization of the parenchyma.

The Eucalyptus genotypes under the second attack level of L. invasa presented greater deformity in the petiole (Figure 3L) than in the vein (Figure 3J). The degree of attack in this genotype not only altered the vascular bundles arrangement, but also their area of occurrence (Figure 4), which decreased as a function of the advanced stage of development of L. invasa larvae (Figure 3L). In the third stage of the wasp attack, the vascular bundles and parenchyma both in the rib (Figure 3J) and the petiole (Figure 3P) suffered severe deformations regarding their organization and coverage area.

In addition to the damage caused by gall development, the adult hatching causes rupture of the vascular, parenchyma and epidermal tissues, opening space for microorganisms. In genotypes with more severe attack, necrosis and leaf drying occur (Figure 4A, B).
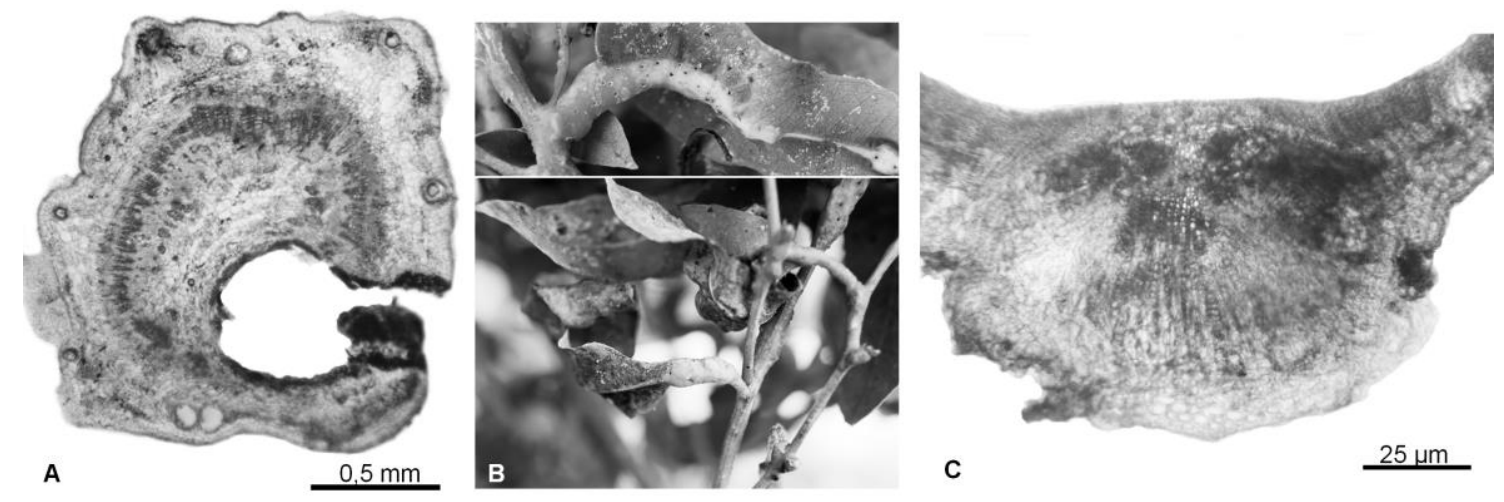

Figure 4: Cross section of Eucalyptus petiole attacked by Leptocybe invasa after adult emergence (a), foliar necrosis (b) and apical region of the leaf with severe attack (c).

Figura 4: Corte transversal do pecíolo de eucalipto atacado por Leptocybe invasa após emergência de adultos (a), necrose foliar (b) e região apical das folhas com ataque severo (c).

The apical region of the leaf only showed deformation in the genotype 1262 under more severe attack (Figure 4C) regarding the organization of vascular bundles and an increase in the area of the parenchyma and cortical tissues. Although the other genotypes presented evident deformations on the vascular bundles in the rib and petiole, the post-attack region remained homogeneous. This result attests to the non-influence of the wasp attack on this region of the leaf; however, sap flow to the apical region can be reduced or disrupted due to the damages caused in the petiole and the rib vein.

Of the three plant regions under gall attack that were addressed in the present study, the rib and petiole showed significant differences between the susceptible and resistant genotypes, which corroborates the different attack levels of the wasps, the genotypes' degree of susceptibility to the attack of this insect and the possibility of damage to the plants due to this attack (Figure 5). In the petiole region, there was a significant difference between the resistant and under attack genotypes; however, only genotype 1262 (whose attack was the most severe) presented significant differences in relation to the resistant genotypes (Figure 5A). In genotype 1724, there was a high variation in the vascular bundle area as a function of the wasp attack, which can be considered an influence of the insect action on these plants, but which was not significant due to the smaller amplitude of the responses (Figure 5A). In 1277 individuals, no difference was observed in relation to the resistant genotype, appearing more resistant than in leaf veins (Figure 5A). 

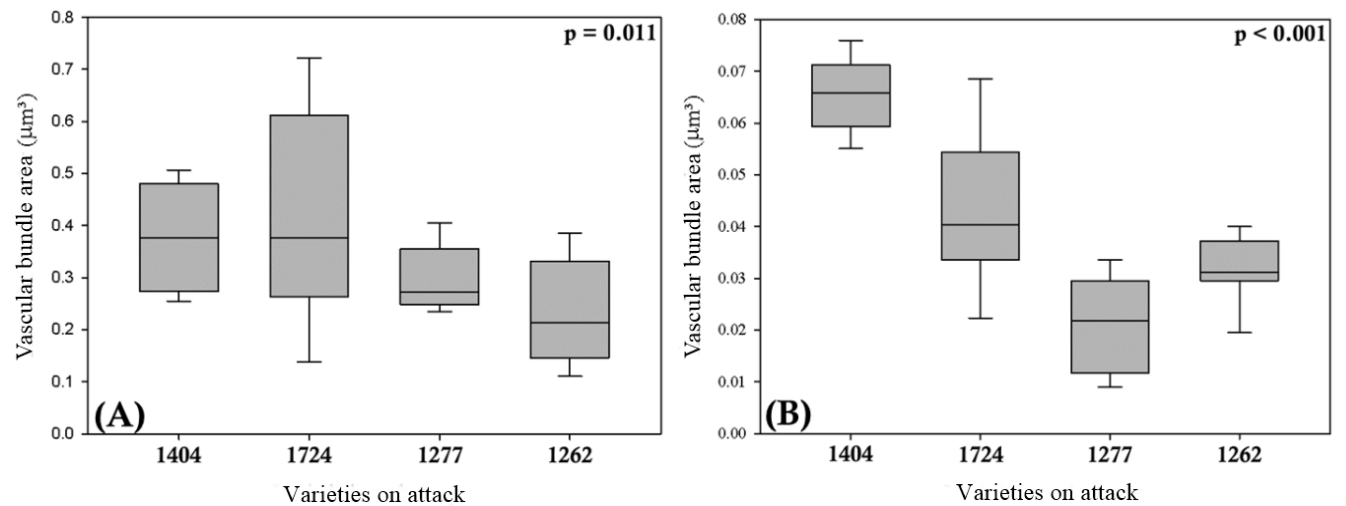

Figure 5: Area of the vascular bundle of petioles (A) and midrib of leaves (B) of Eucalyptus genotypes, resistant (1404) and susceptible $(1724,1277,1262)$ to attack of Leptocybe invasa.

Figura 5: Área do feixe vascular de pecíolos (A) e nervura central de folhas (B) de genótipos de Eucalyptus, resistentes (1404) e suscetíveis $(1724,1277,1262)$ ao ataque de Leptocybe invasa.

The rib region were to all susceptible genotypes significantly different from the resistant individuals, with a gradual variation in the area induced by the attack (Figure 5A). All genotypes under attack showed a reduction in their vascular bundle regions, with the most affected individuals being genotype 1277 with the highest observed reduction and consequent damage to sap conduction (Figure 5A). The apical region of the leaf (post-attack) which it also evaluated, did not present significant differences between the resistant and susceptible genotypes, therefore it is considered that despite the attack before the central vein, there is rearrangement of the vascular bundles in the apical region, which does not acquire significant changes in its beam region due to the attack.

\section{DISCUSSION}

We work with the degree of susceptibility of Eucalyptus genotypes to the formation of galls caused by L. invasa, and what its impact on the anatomy and physiology of plants related to the degree of attack. In general, we observe that the attack of $L$. invasa causes serious structural damages to the leaves, petioles and branches of eucalyptus, as well as the disarrangement of the organic solutes foliar, that interfere directly in the photosynthetic process and consequently in the forestry yield of this taxon.

Macroscopically, the resistant plant (1404) differed of susceptible plants to the development of gall, even though oviposition occurs in its leaves, petiole or branches did not occur the formation of the gall. In the susceptible plants the petioles and midrib of the infested leaves to become numb, causing reduction and deformation of the leaf (Figure 2D, E, F, G, H, I, J, K, L). This leaf aspect was observed by Richardson et al. (2017) in young galls formed in Populus angustifolia James induced by Pemphigus betae Doene (Hemiptera: Aphididae), where the galls exhibited curves in the secondary veins, thereby creating a fold in the abaxial side of the leaf; and by Fernandes et al. (1988) in Myrcia itambensis Berg.

Similar leaf area modifications have been reported by Tong et al. (2016) in E. camaldulensis caused by L. invasa. This reduction influences the absorption of light and probably the photosynthetic process. Larson (1998) reported a reduction of up to $52 \%$ in the photosynthesis rate, comparing leaf mites and leaves with galls, induced by mites in Prunus serotina. Florentine et al. (2005) observed that the presence of galls reduced stomatal conductance, transpiration and photosynthesis in Parthenium hysterophorus induced by the Epiblema strenuana moth.

Under high infestation by L. invasa, Eucalyptus plantations can have their productivity compromised (LAWSON et al. 2012; ZHENG et al. 2014), as the growth of seedlings and trees can be delayed by the presence of massive galls (WILCKEN et al. 2015), mainly the susceptibility genotypes $(1724,1277,1262)$, depending on the infestation can cause plant death (NYEKO et al. 2010). In these plants, the incidence of galls in the young branches compromised the meristematic tissue along with foliar defoliation and dryness, thereby causing loss of apical dominance and consequently axillary buds developed in a packing or burr process, compromising the growth and normal structure of the plants, which lose their commercial value.

The genotype 1404 structurally presented a normal pattern in the vascular bundle, whereas the susceptible genotypes presented modifications and a reduction in the vascular bundle area. This reduction may affect the hydraulic conduction or transport of water to the leaves has been estimated up to $60 \%$, since the conduction is mainly determined by the radius of the conducting vessel and consequently affects the functional characteristics of the leaves (TONG et al. 2016), including photosynthesis.

FLORESTA, Curitiba, PR, v. 51, n. 3, p. 668-676, jul/set 2021.

Dantas, J. O. et.al. 
For growth the plants is dependent on leaf primary productivity, which in turn relies on the function of hydraulic architecture. Therefore, the severe damage to genotypes of Eucalyptus caused by galling of L. invasa is probably lined to change in the function of leaf hydraulic architecture (TONG et al. 2016) and stomatal conductance, a physiological phenomenon that interfere with photosynthesis. Thus probably reduces the photosynthetic rate, decreases primary productivity and reduces plant growth, as observed in the susceptible genotypes tested here.

In addition to the damage caused by the development of gall, the adult wasp that erupts through holes made by them (MENDEL et al., 2004) causes rupture of the vascular tissues, parenchyma and epidermis. The lesions in the vascular tissues decrease the transport of water in the plant (TONG et al., 2016) and elaborated sap, especially when the lesions are in the petioles (Figure 4), hindering the metabolism and the maintenance of the leaves. In genotypes with severe susceptibility, leaf necrosis and drying occurs (Figure 4). The lesions can facilitate the contamination of the tissues of the plant by microorganisms.

\section{CONCLUSIONS}

The analyzes carried out allow us to conclude that:

- Galls cause breakdown and decrease in susceptible plant conduction tissues.

- During adult emergence, tissue disruption allows the entry of microorganisms.

- The ecological and physiological relationships between the galling insect and its hosts have high specificity and can serve as an evolutionary model among the organisms involved.

\section{REFERENCES}

AOYAMA, E. M., LABINAS, A. M. Características estruturais das plantas contra a herbivoria por insetos. Enciclopédia Biosfera, Goiânia, v.8, n.15, p. 365-386. 2012.

BRISOLA, S. H., DEMARCO, D. Análise anatômica do caule de Eucalyptus grandis, E. Urophylla e E. Grandis x E. urophylla: desenvolvimento da madeira e sua importância para a indústria. Scientia Florestalis, Piracicaba, v. 39, n. 91, p. 317-330. 2011.

DITTRICH-SCHRODER, G., WINGFIELD, M. J., HURLEY, B. P., SLIPPERS, B. Diversity in Eucalyptus susceptibility to the gall-forming wasp Leptocybe invasa. Agricultural and Forest Entomology, Pretória, África do Sul, v. 14, n. 4, p. 419-427. 2012.

FERNANDES, G. W. A. F., NETO TAMEIRÃO, E., MARTINS, R. P. Ocorrência e caracterização de galhas entomógenas na vegetação do Campus Pampulha da Universidade de Federal de Minas Gerais. Revista Brasileira de Zoologia, Curitiba, v. 5, n. 1, p. 11-29. 1988.

FERREIRA, B. G., ISAIAS, R. M. S. Developmental stem anatomy and tissue redifferentiation induced by a galling lepidoptera on Marcetia taxifolia (Melastomataceae). Botany, Ontario, Canadá, v. 91, p. 752-760. 2013.

FLORENTINE, S. K., RAMAM, A., DHILEEPAN, K. Effects of gall induction by Epiblema strenuana on gas exchange, nutrients, and energetics in Parthenium hysterophorus. Biological Control, Valbonne, França, v. 50 , p. 787-801. 2005.

FOURNIER, L.A. Un método cuantitativo para la medición de caracteristicas fenológicas en árboles. Turrialba, Turrialba, Costa Rica, v. 24, p. 422-423, 1974.

GONZALEZ, A. M.; SOLÍS, S. M. Anatomía y morfogénesis de las agallas producidas por Leptocybe invasa en plantas de Eucalyptus. Boletín de La Sociedad Argentina de Botánica, Corrientes, Argentina, v. 50, n. 2, p. 141-151. 2015 .

IBA. Relátorio anual da Indústria brasileira de árvores, Poyry consultoria em gestão e negócios Ltda, São Paulo, 2015, 80p.

ISAIAS, R. M. S., CARNEIRO, R. G. S., OLIVEIRA, D. C., SANTOS, J. C. Illustrated and annotated checklist of brasilian gall morphotypes. Neotropical Entomology, Santo Antônio de Goiás, v. 42, p. 230-239. 2013.

ISAIAS, R. M. S., OLIVEIRA, D. C., MOREIRA, A. S. F. P., SOARES, G. L. G., CARNEIRO, R. G. S. The imbalance of redox homeostasis in arthropod-induced plant galls: mechanisms of stress generation and dissipation. Biochimica et Biophysica Acta, Amsterdam, Holanda, v. 1850, n. 8, p. 1509-1517. 2015.

LARSON, K. The impact of two gall-forming arthropods on the photosynthetic rates of their host. Oecologia, Berlin, Alemanha, v. 115, p.161-166. 1998. 
LAWSON., S, GRIFFITHS, M., NAHRUNG, H., NOACK, A., WINGFIELD, M., WILCKEN, C. Biological control of eucalypt pests overseas and in Australia. Report Australian Centre for International Agricultural Research, Bruce, Australia, p. 1-40. 2014.

MAGAlHÃES, T. A., OLIVEIRA, D. C., SUZUKI, A. Y. M., ISAIAS, RMS Patterns of cell elongation in the determination of the final shape in galls of Baccharopelma dracunculifoliae (Psyllidae) on Baccharis dracunculifolia dc (Asteraceae). Protoplasma, Berlin, Alemanha, v. 251, p. 747-753. 2014.

MENDEL, Z., PROTASOV, A., FISHER, N., LA SALLE, J. Taxonomy and biology of Leptocybe invasa gen. \& sp. n. (Hymenoptera: Eulophidae), an invasive gall inducer on Eucalyptus. Australian Journal of Entomology, Cambarra, Austrália, v.43, p.101-113. 2004.

MYBURG, A. A., GRATtAPAGLIA, D., TUSKAN, G. A., HELlSTEN, U., HAYES, R. D., GRIMWOOD, J., JENSKINS, J., LINDQUIST, E., TICE, H., BAUER, D., GOODSTEIN, D. M., DUBCHAK, I., POLIAKOV, A., MIZRACHI, E., KUllaN, A. R. K., HUSSEY, S. G., PINARD, D., MERWE, K., SINGH, P., JAARSVELD, I., SILVA JUNIOR, O. B., TOGAWA, R. C., PAPPAS, M. R., FARIA, D. A., SANSALONI, C. P., PETROLI, C. D., YANG, X., RANJAN, P. The genome of Eucalyptus grandis. Nature, Londres, Inglaterra, v. 510, n. 1, p. 356-374. 2014.

NUGNES, F., GEBIOLA, M., MONTI, M. M., GUALTIERI, L., GIORGINI, M., WANG, J., BERNARDO, H. Genetic diversity of the invasive gall wasp Leptocybe invasa (Hymenoptera: Eulophidae) and of its rickettsia endosymbiont, and associated sex-ratio differences. Plos One, San Francisco, Estados Unidos da América, v.10, p. 1-19. 2015.

NYEKO, P., MUTITU, K. E., OTIENO, B. O., NGAE, G. N., DAY, R. K. Variations in Leptocybe invasa (Hymenoptera: Eulophidae) population intensity and infestation on eucalyptus germplasms in Uganda and Kenya. International Journal Pest management, Abingdon, Reino Unido, v.56, p. 137-144. 2010.

PETRO, R.; MADOFFE, S. S.; IDDI, S.; MUSGASHA, W. A. Impact of Eucalyptus gall wasp, Leptocybe invasa infestation on growth and biomass production of Eucalyptus grandis and E. saligna seedlings in Tanzania. International Journal of Pest Management Reino Unido, v. 61, n. 3, p. 220-227, 2015.

RICHARDSON, R. A., BODY, M., WARMUND, M., SCHULTZ, J. C., APPEL, H. M. Morphometric analysis of young petiole galls on the narrow-leaf cottonwood, Populus angustifolia, by the sugarbeet root aphid, Pemphigus betae. Protoplasma, Berlin, Alemanha, v. 254, n. 1, p. 203-216. 2017.

TONG, Y. G., DING, X. X., ZHANG, K. C., YANG, X., HUANG, W. Effect of the gall wasp Leptocybe invasa on hydraulic architecture in Eucalyptus camaldulensis plants. Frontiers in Plant Science, Lausanne, Suíça, v. 7 , p.1-7. 2016.

TUNG, E. S. C., FREITAS, M. L. M., FLORSHEIM, S. M. B., LIMA, I. L., LONGUI, E. L., SANTOS, F. W., MORAES, M. L. T., SEBBENN, A. M. Variação genética para caracteres silviculturais e anatômicos da madeira em progênies de Myracrodruon urundeuva (Engler) fr. Allem. Scientia Forestalis, Piracicaba, v. 38, n. 87, p. 499-508. 2010.

THU, P. Q., DELL, B., BURGESS, T. I. Susceptibility of 18 eucalyptus species to the gall wasp Leptocybe invasa in the nursery and young plantations in Vietnam. Science Asia, Bangok, Tailândia, v. 35, n. 2, p. 113117. 2009.

WILCKEN, C. F., ZACHÉ, B., MASSON, M. V., PEREIRA, R. A., BARBOSA, L. R., ZANUNCIO, J. C. Vespa-da-galha-do-eucalipto, Lepctocybe invasa Fisher \& La Salle. In: VILELA, EF, ZUCCHI RA Pragas introduzidas no Brasil: insetos e ácaros. Piracicaba: Fealq, 2015, 908 p.

ZHENG, X. L., LI, J., YANG, Z. D., XIAN, Z. H., WEI, J. G., LEI, C. L., WANG, X. P., LU, W. A review of invasive biology, prevalence and management of Leptocybe invasa Fisher \& La Salle (Hymenoptera: Eulophidae: Tetrastichinae). African Entomology, Hatfield, África do Sul, v. 22, p. 68-79. 2014. 